\title{
"Using the Beneish M-score model: Evidence from non-financial companies listed on the Warsaw Stock Exchange"
}

\author{
AUTHORS \\ Artur Hołda (D https://orcid.org/0000-0002-4577-6262 \\ R https://publons.com/researcher/1828750/artur-prof-hoda/
}

Artur Hołda (2020). Using the Beneish M-score model: Evidence from nonfinancial companies listed on the Warsaw Stock Exchange. Investment Management and Financial Innovations, 17(4), 389-401.

doi:10.21511/imfi.17(4).2020.33

DOI http://dx.doi.org/10.21511/imfi.17(4).2020.33

RELEASED ON Tuesday, 22 December 2020

RECEIVED ON Monday, 07 September 2020

ACCEPTED ON

Tuesday, 08 December 2020

\section{(c)) EY}

LICENSE

This work is licensed under a Creative Commons Attribution 4.0 International License

JOURNAL

"Investment Management and Financial Innovations"

ISSN PRINT $1810-4967$

ISSN ONLINE $1812-9358$

PUBLISHER

LLC "Consulting Publishing Company "Business Perspectives"

FOUNDER LLC "Consulting Publishing Company "Business Perspectives"

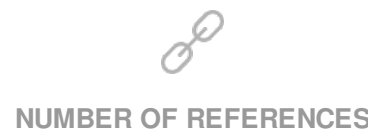

32

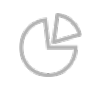

NUMBER OF FIGURES

2

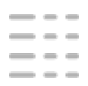

NUMBER OF TABLES

7

(C) The author(s) 2021. This publication is an open access article. 


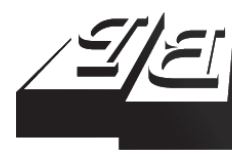

BUSINESS PERSPECTIVES

(2)

LLC "CPC "Business Perspectives" Hryhorii Skovoroda lane, 10, Sumy, 40022, Ukraine www.businessperspectives.org
Received on: $7^{\text {th }}$ of September, 2020 Accepted on: $8^{\text {th }}$ of December, 2020 Published on: $22^{\text {nd }}$ of December, 2020

() Artur Hołda, 2020

Artur Hołda, Associate Professor, Department of Accountancy, Cracow University of Economics. Cracow, Poland.

\title{
USING THE BENEISH M-SCORE MODEL: EVIDENCE FROM NON-FINANCIAL COMPANIES LISTED ON THE WARSAW STOCK EXCHANGE
}

\begin{abstract}
The risk of distortion of financial statements has been growing. Following the 2008 crisis, recipients of financial information are increasingly focusing on the likelihood of financial statements being distorted through fraudulent presentation of financial information. Therefore, scientific research pays more attention to models capable of detecting financial statement manipulation.

The paper aims to present the principles of functioning and the possibility of using the Beneish M-score model in Polish realities. It analyzes the history of more than $30 \mathrm{com}$ panies listed on the Warsaw Stock Exchange to select those whose history indicates that they can be classified as manipulators, and to select the same number of companies from the control group that are considered as non-manipulators.
\end{abstract}

The research method involves the analysis of empirical data on companies listed on the Warsaw Stock Exchange.

The analysis showed the 8-factor Beneish model identified manipulators with $100 \%$ accuracy and succeeded in identifying non-manipulators. The effectiveness of the 5-factor model was much lower.

To serve the purpose of the study, the effectiveness of the Beneish model was tested on a small sample of Polish listed companies as an introduction to a planned larger scale research. The results obtained are consistent with the results of numerous studies by authors from various countries and confirm the effectiveness of the Beneish model in detecting financial statement manipulation.

\section{Keywords}

JEL Classification

\section{INTRODUCTION}

The question of the causes of financial crises is one of the most intriguing in economics. In times of financial turmoil, economists' debate goes even so far as to question the very foundations of capitalism, the market, and the modern economy. The causes of the two crises of the 21 st century as identified by theoreticians - and it is worth noting that the world already saw two financial crises in the first decade of the 21st century: the financial crisis at the beginning of the century sparked by the fall of Enron and the global economic crisis in the wake of by the collapse of Lehman Brothers - include low transparency of financial markets, excessive complexity of financial instruments and a lack of effective warning systems. After the crises, repeated assertions were made claiming that the effectiveness of accounting as an instrument of control was inadequate due to a lack of timely disclosure and expo- 
sure of fraudulent financial reporting by large companies, which led to a failure to prevent the collapse of large entities and subsequent huge losses suffered by investors around the world.

It should be emphasized that preventing global crises requires the creation of early warning systems. This issue is also addressed in this research paper, which deals with the possibility of using the Beneish model to detect potential manipulators and thus avoid the consequences of financial fraud.

Accounting is an integrated information system resulting from the recording, processing and the use of data on business activities. The primary purpose of accounting is to provide quantifiable information about the entity's activities (both past and planned), which will be used for economic assessments by the users of accounting information: internal (owners, managers) and external (banks, leaders, contractors, customers or competitors). However, there is no objective set of accounting rules to be applied to all entities: the complexity of the economic world means that the measurement of business performance requires not only universal principles, but is also based on a high degree of subjectivity in the judgements of those making decisions about what is to be measured and how (Hołda et al., 2006). It is not possible to establish a narrow set of rigid financial accounting standards, therefore, measurement is largely based on human experience, knowledge and imagination, factors which cannot be unified by a more or less detailed set of standards (Staszel, 2020). And the financial scandals of the early twenty-first century have clearly shown that accountants, associated with boring individuals leaning over rows of numbers, in fact are very powerful and can contribute to the collapse of well-known companies or incur huge losses for investors, while it is not true that in accounting the ways of counting are so strictly defined that there is absolutely no room to use your imagination (Fen-May, 2008).

In the case of accounting, a pragmatic information and control system, reliability is of the utmost importance. Historical developments in accounting have seen a constant struggle to defend reliability, particularly in view of the fact that, in the face of increasingly complex economic operations and the activities of individuals in global markets, financial statements are increasingly a collection of information determined by estimation, which makes them vulnerable to manipulation by accountants or management.

There may occur situations (and as history shows, they happen very often) in which intentional distortions or omissions of amounts in financial statements are made. Intentional, i.e. deliberately and, therefore, intentionally deceiving users of financial statements. According to Comiskey and Mulford (2002, pp. 15-16), this procedure can be called fraudulent statements.

Detection of fraudulent financial reporting is possible, inter alia, by using fraud-prediction models. One of the best known models in the world is the Beneish probit model (Omar et al., 2014, pp. 184-186). This paper will present the Beneish model (in two versions: an earlier 8-factor model and a later model reduced to 5 factors) and then check the effectiveness of the model to detect potential "manipulators" using the financial statements of eight companies (selected from among an original sample of over 30 entities) listed on the Warsaw Stock Exchange. The companies were selected in such a way that it is possible to reliably distinguish which of them should be treated as "manipulators" and which are "nonmanipulators", knowing the subsequent events related to these companies. The model was tested on 2010 financial statements in order to be able to determine, based on subsequent events, which company is actually a manipulator and which one is not.

\section{LITERATURE REVIEW}

Manipulative financial reporting was the subject of extensive scientific research as early as the first half of the 20th century (Hepworth, 1953).
Popular methods of detecting earnings manipulation include models for detecting the aggregate value of discretional accruals. There are two types of accrual adjustments: non-discretionary accruals (NDACs) resulting from the entity's operations 
and discretionary accruals (DACs) originating from the management's efforts to manage earnings. The Jones Model (Jones, 1991) is the primary model for accrual adjustments. It was later modified by numerous authors, including Dechow et al. (1995), Dechow and Dichev (2002), McNichols (2002) or Kothari et al. (2005). The basic disadvantage of these models is that DAC estimates are prone to errors. The starting point for accrual-based models are the TAC models, including Healy (1985) and DeAngelo (1986) models. All the above-mentioned models employ financial analysis indicators to calculate the correct values on the basis of which the probability of irregularities is then determined.

Numerous authors have used the Beneish model to verify the scale of financial manipulation in individual countries, including:

1) Paolone and Magazzino (2014), who researched the financial statements of 1,809 listed Italian companies in 2005-2012;

2) Kara, Korpi and Ugurlu (2015), who analyzed the financial statements of 132 Turkish companies listed on the Istanbul Stock Exchange in 2010-2012;

3) Repousis (2016), who analyzed Greek companies' 2011-2012 data;

4) Kaur, Sharma and Khanna (2014), who analyzed data on 332 Indian companies in 2012 and 2013; and

5) Anh and Linh (2016), who researched a sample of 229 non-financial companies listed on the Vietnamese Stock Exchange in 2013-2014.

In all the above-mentioned studies, the results were confirmed, among others, by auditors, and the high efficiency of the Beneish model was demonstrated.

The Polish author Comporek (2018) made an attempt to evaluate the properties of six selected models in Polish realities, pointing to their advantages and disadvantages. An alternative solution to the application of the above-mentioned models is the Beneish model.
In Poland, the number of publications on manipulative financial reporting and the possibility of detecting this practice is still limited relative to the rich scientific achievements in this area in Western Europe and the USA, including, among others, the success of the Beneish model in indicating ENRON's manipulative accounting (based on reports for 1996-2000) (MacCarthy, 2017; Mahama, 2015).

Kaminski et al. (2004) question the effectiveness of financial indicators in detecting irregularities. Meanwhile, Glancy and Yadav (2011) propose to combine the use of financial indicators with the linguistic analysis of reports.

For the purpose of this study, the definition of fraud in the standards applicable in countries with a stabilised market economy may be adopted. One of the first studies - International Standard on Auditing 240A - defines "fraud" as the deliberate misrepresentation of financial information by managers or other persons who may rely on:

1) manipulation, falsification or alteration of accounting records or documents on which they were based;

2) distortion or intentional omission in the financial statements of events, business operations and other material information inconsistent with their contents, and recording of apparent transactions (Association of Certified Fraud Examiners, 1993, p. 12);

3) intentional misapplication of accounting principles; and

4) misappropriation of entity's assets.

For the most recent studies, a clear distinction is made between fraudulent financial reporting as a result of the fraudulent activities listed in (1) to (3) and misappropriation of entity's assets listed in (4).

Table 1 shows the percentage share of fraud detected in the US in 1996, 2002, 2010 and 2018 for these two categories, and the average losses suffered by companies as a result of these practices.

As shown in Table 1, although fraud involving the misappropriation of assets is much more prevalent 
Table 1. The frequency of the two types of fraud and the average losses caused by them in the USA in 1996, 2002, 2010 and 2018

\begin{tabular}{|c|c|c|c|c|c|c|c|c|}
\hline \multirow[b]{2}{*}{ Types of fraud } & \multicolumn{2}{|c|}{1996} & \multicolumn{2}{|c|}{2002} & \multicolumn{2}{|r|}{2010} & \multicolumn{2}{|c|}{2018} \\
\hline & $\begin{array}{c}\text { Share* } \\
\text { (\%) }\end{array}$ & $\begin{array}{l}\text { Average } \\
\text { cost } \\
\text { (thousand } \\
\text { USD) }\end{array}$ & $\begin{array}{c}\text { Share* } \\
\text { (\%) }\end{array}$ & $\begin{array}{c}\text { Average cost } \\
\text { (thousand } \\
\text { USD) }\end{array}$ & $\begin{array}{c}\text { Share* } \\
\text { (\%) }\end{array}$ & $\begin{array}{c}\text { Average cost } \\
\text { (thousand } \\
\text { USD) }\end{array}$ & $\begin{array}{c}\text { Share* } \\
\text { (\%) }\end{array}$ & $\begin{array}{l}\text { Average } \\
\text { cost } \\
\text { (thousand } \\
\text { USD) }\end{array}$ \\
\hline $\begin{array}{l}\text { Fraudulent } \\
\text { financial reporting }\end{array}$ & 4 & 4,000 & 5 & 4,250 & 5 & 4,100 & 6 & 400 \\
\hline $\begin{array}{l}\text { Misappropriation } \\
\text { of assets }\end{array}$ & 81 & 65 & 86 & 80 & 88 & 135 & 88 & 100 \\
\hline Others ** & 15 & 440 & 13 & 530 & 33 & 250 & 47 & 315 \\
\hline
\end{tabular}

Note: $*$ The divisions do not add up to $100 \%$ because some fraudulent activities fall into several categories at once. ** Other cases concern other scams, such as overpricing, the covering of private management expenses with company funds, and corruption.

than fraud in the preparation of financial statements, the losses caused by such fraud are much smaller than those resulting from the fraudulent preparation of financial statements.

Fraudulent financial statements contain intentional misstatements, including omissions of amounts or nondisclosure of information, designed to mislead users of financial statements. This often involves management circumventing controls that otherwise seem to work effectively.

Figures 1 and 2 show the frequency of economic fraud and the distribution of losses resulting from it over the period 2010-2018.

Reports are prepared every two years and indicate that the most common fraud (an average of $86 \%$ of all revealed fraud) is misappropriation (theft) of the assets of individuals, remaining relatively stable over the years. On average, corruption ac- counts for $37 \%$ of all fraud, but it is worth noting that over the analyzed years, there has been a significant increase in corruption-related fraud: from $33 \%$ in 2010 to as much as $47 \%$ in 2018 . On the other hand, the financial statement fraud constitutes a small proportion of all fraud: not more than $1 / 10$ of the cases analyzed. However, in terms of amounts: with respect to the magnitude of the losses caused by a given fraud, by far the biggest losses are caused by the financial statement fraud, as shown in Figure 2.

Although only less than $1 / 10$ of all fraud is related to the financial statement fraud, these fraud cause the biggest losses, but there is a downward trend that can be observed: in 2018, as a result of the increase in the number of the recorded corruption, the biggest losses were caused by both corruption and financial statement fraud. Even though the misappropriation of assets is the most frequently used manipulation (it accounts for more than 4/5

\section{The frequency of the main three types of economic fraud worldwide in the period 2010-2018}

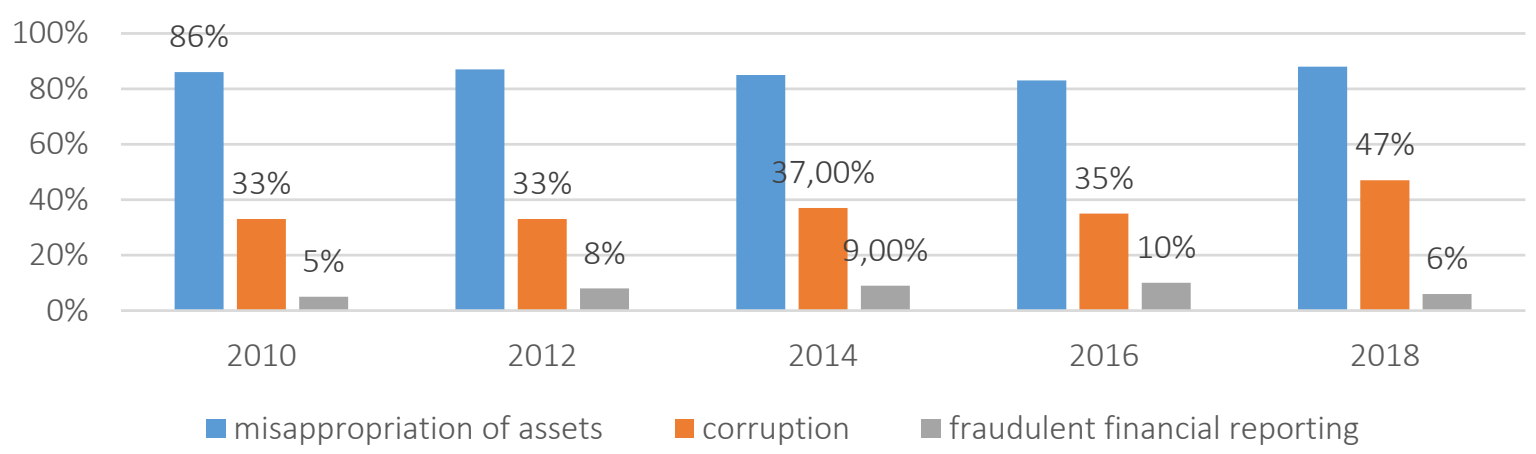

Figure 1. Economic fraud frequency from 2010 to 2018 


\section{The amount of losses (in thousands of USD) incurred as a result of the main three types of fraud worldwide in the period 2010-2018}

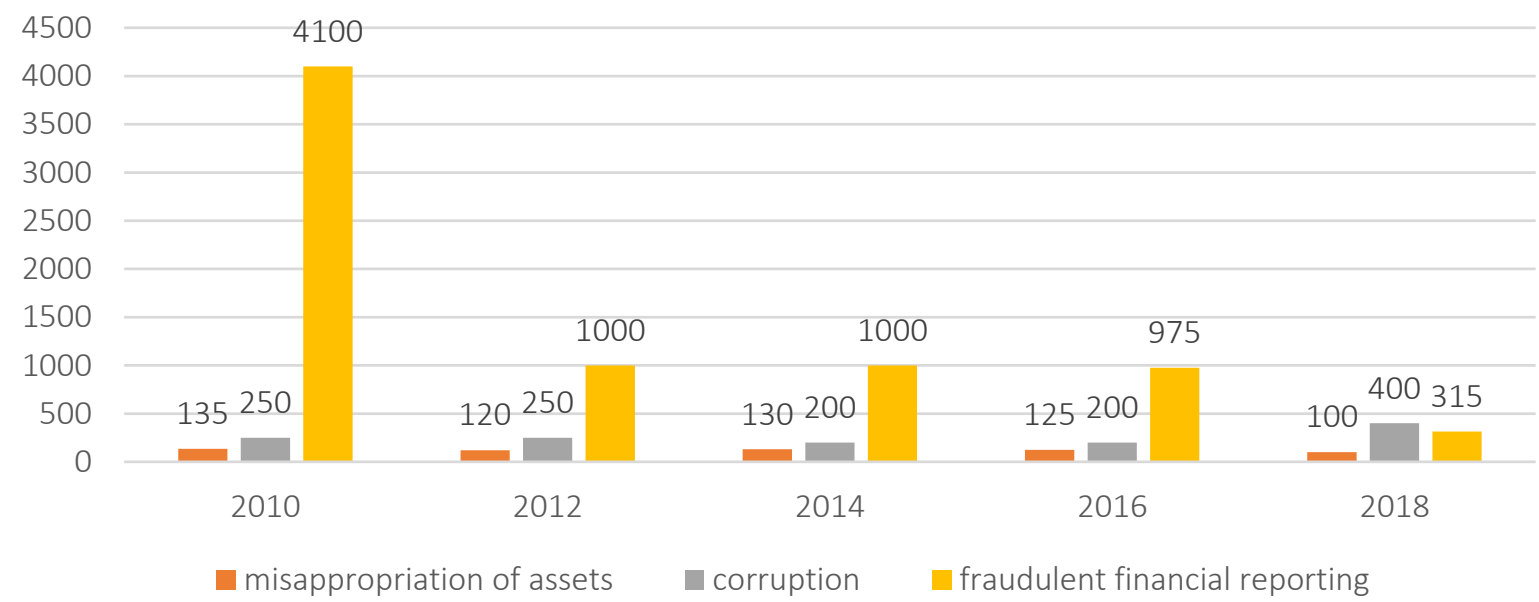

Figure 2. Losses due to economic fraud over the period 2010-2018

of the fraud disclosed), its effects and costs are the lowest, due, among other things, to the high detection rate of these fraud cases. On the other hand, the financial statement fraud (fraudulent financial reporting) takes place through hybrid accounting practices, which makes their identification and subsequent prevention more difficult and, what is more, the losses resulting from this are financially significant in the modern economy.

Detection of fraudulent financial reporting is possible, inter alia, by using fraud-prediction models. One of the best known models in the world is the Beneish probit model.

The model is based on the financial data of 74 companies identified by the U.S. Securities and Exchange Commission (SEC) as manipulators and 2,332 other companies (non-manipulators) for 1982-1992 (Beneish, 1997, pp. 271-309). Beneish (1999), when building the model, relied on the meters that:

- are signalling the future effectiveness of the business;

- $\quad$ are related to cash flow;

- $\quad$ are related to accrual differences; and

- are characterizing managers' motivation to manipulate data.
Based on these three areas, an initial set of eight economic indicators was developed, which was later reduced to five indicators.

The Beneish (1997) study has shown that for average values for individual indicators above 1.08, attention should be paid: these are so-called 'red flags', i.e. areas of special attention.

The aim of the conducted research is to check what will be the indications of the Beneish model for selected companies listed on the Warsaw Stock Exchange. The companies to be tested were selected subjectively, trying to select companies with different "reputation", e.g. a company that received a penalty from the Polish Financial Supervision Authority for giving false data in the financial report, a company that usually receives qualified opinions from the auditors examining its reports, a company that went bankrupt in the subsequent years, and a company that presents transparent and clear data in financial reports that receive unqualified opinions from auditing companies. The history, as well as the opinions of audit firms on their reports of more than 30 companies listed on the WSE, were reviewed to select those whose history clearly indicates that they should be listed as "manipulators", as well as the same number of companies in the control group, in which there are no symptoms of manipulation. 


\section{METHODS}

The study used both the 8-factor and the 5 -factor Beneish models. During proprietary research, the values of individual model factors were calculated and compared with the marginal values proposed by Beneish to assess if the model correctly identifies manipulators.

The indicators showing the areas of manipulation are expressed by the following formula for M-score:

$$
\begin{aligned}
& M_{8-\text { factor }}=-4.84+0.920 \mathrm{DSRI}+ \\
& +0.528 G M I+0.404 A Q I+0.892 S G I+ \\
& +0.115 D E P I-0.172 S G A I+ \\
& +4.679 T A T A-0.327 L V G I,
\end{aligned}
$$

$$
\begin{aligned}
& M_{5-\text { factor }}=-6.065+0.823 D S R I+ \\
& +0.906 G M I+0.593 A Q I+ \\
& +0.717 S G I+0.107 D E P I
\end{aligned}
$$

where DSRI = Days' Sales in Receivables Index, $G M I=$ Gross Margin Index, $A Q I=$ Asset Quality Index, $S G I=$ Sales Growth Index, $D E P I=$ Depreciation Index, $S G A I=$ Sales, General and Administrative expenses Index, $L V G I=$ Leverage Index, TATA - Total Accruals to Total Assets.

At the beginning, the M-score limit for the model was -2.22 . An M-score value above this value indicated that the report could be manipulated. The model was verified in 2004 using a sample of 120 "manipulators" and 67,366 "non-manipulator" companies from 1986-2001 and, as a result of calculations, the M-score level was moved to -1.99 . Finally, in 2012, M.D. Beneish adopted the M-score -1.78 threshold for manipulation of financial statements (Beneish et al., 2013, pp. 57-82).

The DSRI (Day Sales in Receivables Index) is used to assess changes in the level of receivables in relation to the level of sales between year $(t)$ and year $(t-1)$ :

$$
\begin{gathered}
\text { DSRI }=[\text { net receivables }(t) / \text { sales }(t)] / \\
/[\text { net receivables }(t-1) / \text { sales }(t-1) .
\end{gathered}
$$

The DSRI measures whether receivables and revenue (sales) are in balance in two consecutive years.
Therefore, if an increase in receivables disproportionate to the volume of sales is noticed, then such a change may be understood as an effect of artificially inflating revenues from sales. If the company actually manipulates the result through the earlier recognition of revenue, then the effectiveness of this ratio is high. However, an increase in receivables in relation to the volume of sales may also result from a change in the company's credit policy, which is a reaction to an increase in competitiveness on the market.

Another indicator of GMI (Gross Margin Index) is the evaluation of gross margin on sales between the previous and current period.

$$
\begin{gathered}
G M I=\{[\text { sales }(t-1)-\text { cost of goods sold }(t-1)] / \\
\text { sales }(t-1)\} /\{[\text { sales }(t)-\text { cost of goods sold }(t) / \\
\text { sales }(t)\} .
\end{gathered}
$$

The deterioration in sales margin is perceived by the financial market as a negative signal of future probability, and this reduces the effectiveness of the invested capital. This situation is associated with a worse business outlook and higher possibility of manipulation.

The AQI (Asset Quality Index) refers to one of the basic techniques of manipulating financial data, i.e. activating costs. It means that the company's managers try to transfer part of the operating costs from the profit and loss account to the balance sheet.

$A Q I=\{1-[($ current assets $(t)+$ net fixed assets $(t))$ / total assets $(t)]\} /\{1-[($ current assets $(t-1)+$ net fixed assets $(t-1)) /$ total assets $(t-1)]\}$,

SGI (Sales Growth Index):

$$
S G I=[\operatorname{sales}(t)] /[\operatorname{sales}(t-1)]
$$

An increase in sales in the company is not a signal of manipulative practice by managers. However, as in the case of the gross margin indicator, it represents positive expectations on the part of the capital market, and thus exerts pressure on company managers to achieve forecasts formulated by analysts in terms of the effects achieved (MacCarthy, '2017). 
The SGAI (Sales General and Administrative Expenses Index) is used to assess the change in the share of sales and general and administrative expenses in sales revenue between period $(t)$ and period $(t-1)$.

$S G A I=[$ (selling, general \& administrative expense $(t)+$ sales $(t)) /$ sales $(t)] /[($ selling, general $\&$ administrative expense $(t-1)+$ sales $(t-1))$ / sales $(t-1)]$.

Essentially, the application of the SGAI is related to the assessment of disproportionate changes in sales revenues. In this case, the evaluation is carried out in relation to administrative costs and selling expenses. The focus on the assessment of the proportionality of changes in sales volumes results from the conviction that any disproportions observed in this area may mean interference of managers in the reporting process.

Negative deviations within the framework of the presented indicators point to areas that require deeper interest from analysts or auditors. Their assessment indicates symptoms of fraudulent activity of managers.

Other indicators not included in the five-factor model are:

DEPI (Depreciation Index), which is the quotient of the value of a measure that determines the ratio of depreciation to gross fixed assets between periods $(t-1)$ and $(t)$.

DEPI $=[$ depreciation $(t-1) /($ depreciation $(t-1)$ + net assets $(t-1))$ ] / [depreciation $(t) /$ (depreciation $(t)+$ net assets $(t))]$.

A decrease in the overall depreciation rate below 1 may indicate that the company has reduced depreciation rates or extended the depreciation period. This results in lower operating costs, which, in turn, leads to a higher financial result.

Another LVGI (Leverage Index) is the ratio of the total debt level between year $(t)$ and $(t-1)$. An increase in debt is a bad signal for financial risk assessment. This, in turn, increases the managers' motivation to improve the image of the company in the financial statements.
LVGI $=$ [current liabilities $(t) /$ total assets $(t)] /$

[current liabilities $(t-1) /$ total assets $(t-1)$ ].

The last indicator of the presented model, TATA (Total Accruals to Total Assets), shows the relation of the total sum of accrual differences to total assets. Within this indicator, the total sum of accrual differences is determined as the difference between net profit and cash flows from operating activities (based on the findings of the cash flow statement), or the balance sheet method:
TATA $=(\Delta$ net working capital $-\Delta$ cash and equiv- alents- $\Delta$ income tax - depreciation)
/ total assets $(t)$.

A high level of TATA means that managers can take advantage of accounting manipulation.

The research aimed at testing the Beneish model in practice on Polish companies included eight companies listed on the Warsaw Stock Exchange. The verification was carried out for 2010 knowing what subsequent events related to the financial statements of these companies took place. The structure of the analyzed entities is presented in Table 2 .

The following units were selected for the test sample:

a. Companies that have received a fine from the Polish Financial Supervision Authority for irregularities related to the financial statements in later years than the analyzed ones (which may also indicate that they had already manipulated the financial statements before). These are the companies marked Alpha and Beta.

b. A company that has received a disclaimer opinion by the auditors examining its financial statements (in years later than those covered by the analysis, which may also suggest that it had already manipulated them). This is a company marked as Gamma.

c. A company that for both the year under review and the subsequent years received notoriously qualified opinions due to irregularities identified in the statements. This is a company marked as Delta. 
Table 2. Structure of companies tested with the Beneish model

\begin{tabular}{|c|c|c|}
\hline Company & $\begin{array}{c}\text { Industry in which the company operates } \\
\text { (according to the classification on the WSE } \\
\text { website) }\end{array}$ & Events related to this company \\
\hline Alpha Company & Retail & $\begin{array}{l}\text { The Company received a fine from the Polish Financial } \\
\text { Supervision Authority in connection with the irregularities in } \\
\text { the financial statements for, among others, } 2011\end{array}$ \\
\hline Beta Company & Services - other & $\begin{array}{c}\text { The Company received several times a fine from the Polish } \\
\text { Financial Supervision Authority in connection with the } \\
\text { irregularities in the financial statements }\end{array}$ \\
\hline Gamma Company & Wood and paper industry & $\begin{array}{l}\text { In the following years, the company received a disclaimer of } \\
\text { opinion on the financial statements in one of the following } \\
\text { years, later it declared bankruptcy }\end{array}$ \\
\hline Delta Company & Pharmaceutical industry & $\begin{array}{l}\text { The Company has repeatedly received a qualified opinion in } \\
\text { connection with the irregularities in the financial statements }\end{array}$ \\
\hline Dzeta Company & Wholesale & Control company (no significant events) \\
\hline Eta Company & Food industry & Control company (no significant events) \\
\hline Theta Company & Food industry & Control company (no significant events) \\
\hline lota Company & Retail & Control company (no significant events) \\
\hline
\end{tabular}

d. Companies referred to as "control companies", i.e. companies in which none of the events listed in points a) - c) occurred. These companies were named Dzeta, Eta, Theta and Iota.

Finally, Alpha, Beta, Gamma, Delta were classified as "manipulators", while Dzeta, Eta, Theta and Iota were classified as "non-manipulators". The aim of the research was to check (on the basis of an analysis of the financial statements of 8 analysed companies for the years 2009 and 2010) whether the calculations and indication of the Beneish model for these companies would correctly identify manipulators and non-manipulators. The year 2010 was deliberately chosen as the year subject to analysis, thanks to which it is known what was the further fate of these entities, and based on the history of these companies, it was possible to correctly classify them as a group of manipulators (entities on which supervisory authorities were imposed or received modified opinions on financial statements due to distortions occurring in these statements, however, these events concerned both the year 2010 and e.g. 2011, which indicates permanent manipulation of financial data) and non-manipulators (entities in which in none of the following years did any event occur, which could indicate that these units are manipulators).

\section{RESULTS}

At the first stage of the study, the number of "red" flags was determined for each company by means of individual indicators used in the Beneish model (the study was conducted on the basis of an 8-factor model), i.e. it was determined in which entities the most indicators exceeded -1.08 . The results are presented in Table 3.

For each entity, the value of the indicator and whether it is a 'red flag' are given. The last columns of Table 3 contain the number of red flags for a given company.

The analysis of the number of red flags in companies that could be considered as manipulators and control companies shows that the entities fined by the PFSA received a disclaimer opinion from auditors or notoriously maintained qualified opinions; the number of red flags is higher than that of entities from the control group.

Table 4 shows the number of red flags and the number of missing red flags in the control companies and in other companies (initially assigned to the group of "manipulators").

As Table 4 shows, the number of red flags is much more frequent among the manipulator companies (these companies received almost $2 / 3$ of all red flag indications) and much smaller among the control group companies (considered as "non-manipulators").

Next, the value of the M-score index of the Beneish model was calculated for the analyzed companies; calculations were made for both the 8-factor and 
Table 3. Values of indicators from the Beneish model and the number of red flags in the analyzed companies calculated for financial statements prepared for 2010

\begin{tabular}{|c|c|c|c|c|c|c|c|c|c|c|c|c|c|c|c|c|c|}
\hline Company & $\begin{array}{l}\text { Company } \\
\text { information }\end{array}$ & $\overline{\widetilde{c}}$ & 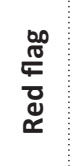 & $\overline{\mathrm{N}}$ & 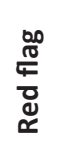 & $\bar{\sigma}$ & 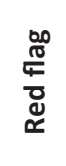 & W & 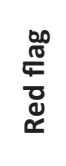 & 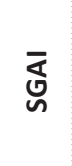 & 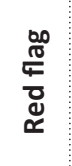 & 高 & $\begin{array}{l}\infty \\
\mathbb{t} \\
\mathbb{T} \\
\mathbb{d} \\
\mathbb{d}\end{array}$ & ড & 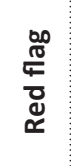 & $\frac{\mathbb{E}}{\mathbb{E}}$ & 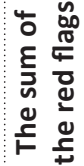 \\
\hline Alpha & PFSA's fine & 1.34 & YES & 1.00 & & 0.34 & & 1.09 & YES & 1.48 & YES & 5.48 & YES & 0.85 & & 0.55 & 4 \\
\hline Beta & PFSA's fine & 0.73 & & 1.06 & & 3.68 & YES & 1.78 & YES & 0.86 & & 0.37 & & 1.04 & & -0.15 & 2 \\
\hline Gamma & $\begin{array}{l}\text { Modified opinion } \\
\text { (refusal of opinion) }\end{array}$ & 0.71 & & 0.97 & & 1.13 & YES & 0.89 & & 1.43 & YES & 680.54 & YES & 1.16 & YES & -0.18 & 4 \\
\hline Delta & $\begin{array}{l}\text { Modified opinion } \\
\text { (subject to } \\
\text { change) }\end{array}$ & 0.32 & & 0.03 & & 1.41 & YES & 3.01 & YES & 0.30 & & 0.62 & & 0.68 & & -0.05 & 2 \\
\hline Dzeta & & 0.98 & & 0.88 & & 1.03 & & 1.05 & & 1.05 & & 0.75 & & 1.01 & & 0.01 & 0 \\
\hline Eta & & 1.04 & & 0.98 & & 0.87 & & 1.21 & YES & 0.94 & & 1.05 & & 1.01 & & 0.01 & 1 \\
\hline Theta & & 0.63 & & 0.96 & & 1.12 & YES & 0.97 & & 1.08 & & 6.86 & YES & 1.02 & & -0.03 & 2 \\
\hline lota & & 2.16 & YES & 0.76 & & 1.52 & YES & 1.68 & YES & 1.04 & & 1.08 & & 2.21 & YES & -0.23 & 4 \\
\hline
\end{tabular}

Table 4. Number of "red flags" in companies tested with the Beneish model

\begin{tabular}{l|c|c}
\hline & $\begin{array}{c}\text { Number of cases and percentage } \\
\text { of missing red flags }\end{array}$ & $\begin{array}{c}\text { Number and percentage of red } \\
\text { flags }\end{array}$ \\
\hline Control companies: Dzeta, Eta, Theta, lota & $25(55 \%)$ & $7(37 \%)$ \\
\hline "Manipulator" companies: Alpha, Beta, Gamma, Delta & $20(44 \%)$ & $12(63 \%)$ \\
\hline
\end{tabular}

the 5-factor models, in both models assuming the limit value of " -1.78 ".

The results for 8 -factor and 5 -factor models are summarized in Table 5.

In the case of the Alpha and Beta companies, on which the PFSA has repeatedly imposed fines, the 8 -factor Beneish model indicated manipulation of financial data. The 5 -factor model only pointed to the Beta company as a manipulator. The same situation occurred with regard to the companies that received modified opinions on their financial statements: the 5-factor model indicated only one company, and the 8 -factor model correctly indicated both companies as manipulators.
It can also be observed that the model significantly indicated manipulations in entities where either disclaimer opinion or qualified opinion took place. Again, the 8-factor model correctly indicated these companies as potential manipulators, the 5 -factor model indicated only Gamma company.

In the case of the entities deemed not to be manipulators, the 8 -factor model indicated manipulations for none of these companies, while the 5 -factor model indicated one of the companies in the control group as a manipulator.

Table 6 presents the collected data for the 5 -factor model: the table collects the number of indications of the Beneish model for the manipulation

Table 5. Aggregate values using 5-factor and 8-factor models for the analyzed companies

\begin{tabular}{|c|c|c|c|c|c|}
\hline Company & Company information & 5-factor model & $\begin{array}{l}\text { Indication of } \\
\text { manipulation }\end{array}$ & 8-factor model & $\begin{array}{l}\text { Indication of } \\
\text { manipulation }\end{array}$ \\
\hline Alpha & PFSA's fine & -2.49 & $\mathrm{NO}$ & 0.70 & YES \\
\hline Beta & PFSA's fine & -1.00 & YES & -1.68 & YES \\
\hline Gamma & Modified opinion & 69.52 & YES & 74.37 & YES \\
\hline Delta & Modified opinion & -2.72 & NO & -1.74 & YES \\
\hline Dzeta & & -3.01 & NO & -2.49 & NO \\
\hline Eta & & -2.82 & NO & -2.27 & NO \\
\hline Theta & & -2.58 & NO & -2.28 & NO \\
\hline lota & & -1.38 & YES & -2.21 & NO \\
\hline
\end{tabular}


Table 6. Number of indications of the Beneish 5-factor model for "manipulator" and "non-manipulator" companies

\begin{tabular}{l|c|c}
\hline & $\begin{array}{c}\text { The Beneish model indicates } \\
\text { financial data manipulation }\end{array}$ & $\begin{array}{c}\text { The Beneish model does not indicate } \\
\text { financial data manipulation }\end{array}$ \\
\hline Control companies: Dzeta, Eta, Theta, lota & 1 & 2 \\
\hline "Manipulator" companies: Alpha, Beta, Gamma, Delta & 2 & 2 \\
\hline
\end{tabular}

of reporting data and for the lack of manipulation of reporting data by companies classified as the "manipulators" group (i.e. companies with a fine imposed by the PFSA, a company that was refused an opinion, and a company that repeatedly received qualified opinions from the auditors) and the "non-manipulators" group.

The Beneish 5-factor model indicated manipulations in companies actually classified as manipulators in only $50 \%$ of cases, while in $50 \%$ of companies, it indicated that these companies are not classified as manipulators. In the case of the control group, the indications were more accurate: the model correctly indicated for $3 / 4$ of the companies that there were no grounds to consider them as manipulators, one of the four companies in the control group was indicated by the model as manipulator.

Table 7 shows the collected data for the 8 -factor model: the table shows the number of indications of the Beneish model for the manipulation of reporting data and for the lack of manipulation of reporting data by companies classified as the "manipulators" group (i.e. companies with a fine imposed by the PFSA, a company that was refused an opinion, and a company that repeatedly received qualified opinions from auditors) and the "non-manipulators" group.

When analyzing the results obtained by applying the 8-factor Beneish model for eight listed companies for 2010, knowing what events took place in these entities in subsequent years, it should be pointed out that this model indicated with $100 \%$ precision which companies are the manipulators (as confirmed by subsequent events). The model also indicated, in the case of control group companies (where there is no indication of financial data manipulation), that it does not identify these companies as "manipulators".

To sum up, the 8-factor Beneish model is an effective tool for identifying entities that manipulate data contained in financial statements in relation to Polish listed companies. Interestingly, the 5 -factor model no longer shows such effectiveness.

\section{DISCUSSION}

Eight companies listed on the WSE were used as the research sample. To confirm the effectiveness of the model in the Polish market conditions, it was planned to conduct research on a larger research sample. However, it is interesting to note that the 8-factor model, i.e. the first version of the Beneish M-score model, is more effective in detecting manipulation in the Polish realities than the 5-factor model. To the author's best knowledge, however, no large scale studies have been undertaken on Polish companies listed on the Warsaw Stock Exchange.

Inspired by the numerous foreign studies into the effectiveness of the Beneish model, this study initiates scientific research into Polish companies aiming to show the adequacy of the model in the Polish economic realities.

Paragraph A2 of the International Standard On Auditing 240 “The Auditor's Responsibilities Relating To Fraud In An Audit Of Financial

Table 7. Number of indications of the Beneish 8-factor model for "manipulator" and "non-manipulator" companies

\begin{tabular}{l|c:c}
\hline & $\begin{array}{c}\text { The Beneish model indicates } \\
\text { financial data manipulation }\end{array}$ & $\begin{array}{c}\text { The Beneish model does not indicate } \\
\text { financial data manipulation }\end{array}$ \\
\hline Control companies: Dzeta, Eta, Theta, lota & 0 & 4 \\
\hline "Manipulator" companies: Alpha, Beta, Gamma, Delta & 4 & 0 \\
\hline
\end{tabular}


Statements" notes that fraudulent financial reporting can be driven by management's desire to shape revenue in such a way as to deceive users of financial statements by influencing their perception of an entity's performance and profitability. These practices, called earnings management (translated as "profit management", "income shaping" or "profit shaping") may, according to the standard, originate in inappropriate adjustments to assumptions and changes in management's judgement. The ISA 240 stresses that in the case of earnings management, management deliberately adopts attitudes leading to fraudulent financial reporting caused by significant distortions in the financial statements (Ronen \& Yaari, 2008, p. 581).

It can be said that "accounting fraud" should be understood as actions that are:

a. Illegal (including, but not limited to, criminal, civil, economic and, above all, 'balance sheet' activities") (Magrath \& Weld, 2002, pp. 51-54).

b. Intentional.

c. Concealed.

d. Intended to mislead the recipient of economic information and

e. Aiming at gaining an undue advantage (not necessarily strictly property-based).

Techniques to facilitate the analysis of fraud risk factors may include, in particular: a technique for the analysis of 'red flags', which includes lists (statements) listing the factors conducive to fraud ("red flags") (Zack, 2009);

- techniques based on statistical models using the frequency of individual factors in companies where fraud has been detected and those where no fraud has been detected;

- techniques using expert systems for factor analysis.

In turn, the most famous fraud detection models include the Beneish probit model (Mahama, 2015). Professor Messod Daniel Beneish of Indiana University has researched the financial data of 74 companies that have been identified by the US Securities and Exchange Commission (SEC) as manipulators and 2,332 other public companies for 1982-1992. Beneish, in building the model, relied on measures indicating the future effectiveness of its business, cash flow and accrual differential measures and measures that characterize managers' motivation to manipulate data. Originally, the 8-factor model was developed based on this data set. Then a 5 -factor model was created; however, as the literature analysis shows, there is less interest in this model. Authors most often check the functioning of the 8 -factor model in practice, even the author of the model himself in his 2012 paper tested the 8 -factor model, although there are also studies indicating that the factors listed in the 5-factor model are important (Herawati, 2015, pp. 924-930).

\section{CONCLUSION}

The study described in this research paper aimed to verify whether the Beneish model, repeatedly tested on companies from around the world by numerous authors, will prove its effectiveness in the Polish economic realities. If the hypothesis predicting that this model can be used in Poland without significant modifications is confirmed, it could become an effective tool for use by regulatory bodies, chartered accountants or the tax authorities to identify entities suspected of manipulation.

Using the model in practice would not, of course, consist in singling out the manipulator, but rather in pointing to an entity that should be subjected to a profound check, as the model indicates that manipulation may have taken place.

For the purpose of this research paper, a certain number of Polish listed companies were scrutinized to verify the hypothesis. 
The analysis presented in this study on a group of eight companies, whose history after 2010, for which the analysis was made, makes it possible to determine which of these companies should be considered as manipulators and which should not, also showed that in the Polish economic conditions, the 8-factor model proved to be better than the 5-factor model. The research carried out based on the survey fn a group of eight companies listed on the WSE (the companies were deliberately selected in such a way as to make it clear which of them should be considered as manipulators and which of them should not) showed that the 8-factor Beneish model pointed to "manipulators" with 100\% effectiveness and was also not mistaken even once for "non-manipulators".

The results of the study demonstrate that the Beneish model successfully identifies Polish "manipulator" companies, thus confirming the results of studies obtained by authors from other countries, which also indicate the effectiveness of the Beneish model in those countries.

The analyzed research sample was small, therefore, in order to fully confirm the effectiveness of the Beneish model in Polish realities, it is necessary to conduct an in-depth study into a larger group of companies, which will extend the research the results of which are described in this paper.

The main conclusion to be drawn from the study is that the Beneish model can be used as a tool for identifying financial statement manipulation, including in Polish companies.

\section{ACKNOWLEDGMENT}

The publication is sponsored by funds from the Cracow University of Economics for the maintenance and development of research potential.

\section{AUTHOR CONTRIBUTIONS}

Conceptualization: Artur Hołda.

Data curation: Artur Hołda.

Formal analysis: Artur Hołda.

Investigation: Artur Hołda.

Methodology: Artur Hołda.

Writing - original draft: Artur Hołda.

Writing - review \& editing: Artur Hołda.

\section{REFERENCES}

1. Anh, N. H., \& Linh, N. H. (2016).

Using the M-score Model in Detecting Earnings Management: Evidence from Non-Financial Vietnamese Listed Companies VNU. Journal of Science: Economics and Business, 32(2), 14-23. Retrieved from https://js.vnu.edu.vn/EAB/ article/view/1287

2. Association of Certified Fraud Examiners (1993). Cooking the Books. What Every Accountant Should know about Fraud. Austin: ACFE.

3. Beneish, M. D. (1999). The detection of earnings manipulation.
Financial Analysts Journal, 55(5), 24-36. https://doi.org/10.2469/faj. v55.n5.2296

4. Beneish, M. D., Lee, C. M. C., \& Nichols, D. C. (2002). Earnings Manipulation and Expected Returns. Financial Analysts Journal, 69(2), 57-82. https://doi.org/10.2469/faj. v69.n2.1

5. Beneish, M. D (1997). Detecting GAAP violation: Implications for assessing earnings management among firms with extreme financial performance. Journal of Accounting and Public Policy, 16(3), 271-309.
https://doi.org/10.1016/S0278-

4254(97)00023-9

6. Comiskey, E. E., \& Mulford Ch. W. (2002. The Financial Numbers Game. Detecting Creative Accounting Practices. New York: John Wiley \& Sons.

7. Comporek, M. (2018). Możliwości i ograniczenia wykorzystania modeli memoriałowych korekt zysku netto w detekcji zarządzania zyskiem. Zeszyty Teoretyczne Rachunkowości, 100(156), 49-66. Retrieved from http://cejsh.icm.edu. $\mathrm{pl} /$ cejsh/element/bwmeta1.element. desklight-6c756dad-35f7-484d90ca-34b218e6978a 
8. De Angelo, L. (1986). Accounting numbers as market valuation substitutes: a study of management buyouts of public stockholders. The Accounting Review, 61(3), 400-420. Retrieved from https://www.jstor. org/stable/247149? seq=1

9. Dechow, P. M., \& Dichev, I. (2002). The quality of accruals and earnings: The role of accrual estimation errors. The Accounting Review, 77(Supplement), 35-59. https://doi. org/10.2308/accr.2002.77.s-1.35

10. Dechow, P. M., Richardson, S. A., \& Tuna I. (2003). Why are earnings kinky? An examination of the earnings management explanation. Review of Accounting Studies, 8(2-3), 355-384. https://doi.org/10.1023/ A\%3A1024481916719

11. Dechow, P. M., Slowan, R. G., Sweeney, A. P. (1995). Detecting Earnings Management. The Accounting Review, 70(2), 193-225. Retrieved from https://www.jstor. org/stable/248303?seq=1

12. Fen-May, L. (2008). Fraudulent financial reporting detection and business failure prediction models: a comparison. Managerial Accounting Journal, 23(7), 650-662. https://doi. org/10.1108/02686900810890625

13. Glancy, F. H., \& Yadav, S. B. (2011). A computational model for financial reporting fraud detection. Decision Support Systems, 50(3), 595-601. https://doi.org/10.1016/j. dss.2010.08.010

14. Healy, P. M. (1985). The Effect of Bonus Schemes on Accounting Decisions. Journal of Accounting and Economics, 7(1-3), 85-107. https://doi.org/10.1016/01654101(85)90029-1

15. Hepworth, S. R. (1953). Smoothing Periodic Income. The Accounting Review, 28(1). 32-39. Retrieved from https://www.jstor.org/stable/241436

16. Herawati, N. (2015). Application of Beneish M-Score Models and Data Mining to Detect Financial Fraud. Procedia - Social and Behavioral Sciences, 211(25), 924-930. https://doi. org/10.1016/j.sbspro.2015.11.122

17. Hołda, A., Kutera, M., \& Surdykowska S. (2006). Oszustwa finansowe. Warsaw: Difin.
18. Jones, J. (1991). Earnings Management during Import Relief Investigations. Journal of Accounting Research, 29(2), 193-228. Retrieved from https://www.jstor.org/stable/24 91047? origin $=$ crossref $\&$ seq $=1$

19. Kaminski, K. A., Wetzel, T. S., \& Guan, L. (2004). Can financial ratios detect fraudulent financial reporting? Managerial Auditing Journal, 19(1), 15-28. Retrieved from https:// www.researchgate.net/deref/ http\%3A\%2F\%2Fdx.doi.org\%2F10. 1108\%2F02686900410509802

20. Kara, E., Korpi, M., \& Ugurlu, M. (2015). Using Beneish model in identifying accounting manipulation: an empirical study in BIST manufacturing industry sector. Journal of Accounting, Finance and Auditing Studies, 1(1), 2139. Retrieved from https://www. semanticscholar.org/paper/ Using-Beneish-Model-in-Identifying-Accounting-An-in-SanayiiRegresyon/eae6bdaca983d10a6931441554481805f9aeab8d

21. Kaur, R., Sharma, K., \& Khanna, A. (2014). Detecting Earnings Management in India - A sectorwise Study on European. Journal of Business and Management, 6(11), 11-18. Retrieved from https:// www.researchgate.net/publication/264343764_Detecting_Earnings_Management_in_India_A_ sector-wise_study

22. Kothari, S. P., Leone, A., \& Wasley, C. (2005). Performance matched discretionary accrual measures. Journal of Accounting and Economics, 39(1), 163-197. https://doi. org/10.1016/j.jacceco.2004.11.002

23. MacCarthy, J. (2017). Using Altman Z-score and Beneish M-score Models to Detect Financial Fraud and Corporate Failure: A Case Study of Enron Corporation. International Journal of Finance and Accounting, 6(6), 159-166. Retrieved from https://www.researchgate.net/ publication/321143663_Using_ Altman_Z-score_and_Beneish_Mscore_Models_to_Detect_Financial_ Fraud_and_Corporate_Failure_A_ Case_Study_of_Enron_Corporation

24. Magrath, L., \& Weld, L. G. (2002). Abusive earnings management and early warnings signs. The $C P A$ Journal, 72(8), 51-54. Retrieved from: https://www.researchgate.net/ publication/285201381_Abusive_ earnings_management_and_early_ warning_signs

25. Mahama, M. (2015). Detecting corporate fraud and financial distress using the Altman and Beneish models. International Journal of Economics, Commerce and Management, 3(1), 1-18. Retrieved from https:// www.semanticscholar.org/paper/ DETECTING-CORPORATEFRAUD-AND-FINANCIALDISTRESS-Kingdom-Mahama/04 e191740a686da55ea4370a4afe267d d61d6c97

26. Mcnichols, M. (2002). Discussion of the quality of accruals and earnings: The role of accrual estimation errors. The Accounting Review, 77(Supplement), 61-69. https://doi. org/10.2308/accr.2002.77.s-1.61

27. Omar, N., Koya, R. K., Sanusi, Z. M., \& Shafe, N. A. (2014). Financial statement fraud: A Case examination using Beneish model and ratio analysis. International Journal of Trade, Economics and Finance, 5(2), 184-186. Retrieved from http://www. ijtef.org/index.php? $\mathrm{m}=$ content $\& \mathrm{c}=\mathrm{i}$ ndex $\& \mathrm{a}=$ show $\&$ catid $=50 \& \mathrm{id}=664$

28. Paolone, F., \& Magazzino, C. (2014). Earnings manipulation among the main industrial sectors: Evidence from Italy. Economia Aziendale, 5, 253-261. Retrieved from https:// www.researchgate.net/publication/276266980_Earnings_Manipulation_among_the_Main_Industrial_Sectors_Evidence_from_Italy

29. Repousis, S. (2016). Using Beneish model to detect corporate financial statement fraud in Greece. Journal of Financial Crime, 23(4), 1063 1073. Retrieved from https:// www.researchgate.net/publication/311481922_Using_Beneish_ model_to_detect_corporate_financial_statement_fraud_in_Greece

30. Ronen, J., \& Yaari, V. (2008). Earnings management. New York: Springer.

31. Staszel, A. (2019). Obszar swobody w rachunkowośc. Warsaw: Difin.

32. Zack, G. M. (2009). Fair Value Accounting Fraud New Global Risks and Detection Techniques. New Jersey: John Wiley \& Sons. 